\title{
NARRATIVAS PÚBLICAS E CONSTITUCIONALISMO NA ABDICACÃO DE D. PEDRO I EM
}

Em um momento de intensas disputas políticas em torno da organização da ordem constitucional no final do Primeiro Reinado, as narrativas, entendidas como relatos que misturavam rumores, fatos e emoções, disseminaram-se amplamente na esfera pública. Analisaremos em que medida e de que maneira essas narrativas - a recolonização do Brasil e a do

RESUMO Imperador antinacional - geraram comportamentos que contribuíram para a Abdicação. A partir de referenciais analíticos sobre a disseminação de narrativas e rumores, concluiu-se, que as narrativas estimularam comportamentos que as confirmavam e assim amplificaram seus efeitos, reunindo grupos com demandas diversas em torno de uma causa comum, o que contribuiu para deslegitimar a figura do imperador.

Palavras-chave: Brasil Império; Constitucionalismo; D. Pedro I.

\section{ABSTRACT}

At a time of intense political disputes over the organization of the constitutional order at the end of the reign of Pedro I, the narratives, which can be understood as stories that mixed rumors, facts and emotions, were widely disseminated in the public sphere. We analyze in this text to what extent and in what way those narratives - the recolonization of Brazil and the stories about a supposed anti-nationalism of the Emperor - generated behaviors that contributed to Abdication. Based on analytical references on the dissemination of narratives and rumors, we conclude that the narratives stimulated behaviors that self-confirmed them and thus amplified their effects, contributing to bring together groups with diverse demands around a common cause, which contributed to delegitimize the figure of the emperor.

Keywords: Brazil Empire; Constitutionalism; D. Pedro I.

* Doutora em História pela Universidade Estadual Paulista Júlio de Mesquita Filho (Unesp-Assis). Pós-doutorado em História pela Universidade Federal do Espírito Santo. E-mail: ferpandolfi@hotmail.com. 


\section{INTRODUCÃO}

No Brasil do século XIX, uma nova cultura política emergiu com a Revolução do Porto de 1820 e redefiniu de forma significativa a vida política. Os revolucionários do Porto defendiam a formulação de uma Constituição em Portugal e de um Poder legislativo para conter os abusos do Antigo Regime. Apesar da inicial adesão das elites no Brasil às ideias vindas do Porto, as determinações das Cortes Portuguesas em 1821-1822 acabaram sendo vistas como recolonizadoras. Nesse contexto, houve um pacto em torno da figura de D. Pedro I como a opção mais segura para os interesses das elites, apesar da existência de projetos que não vislumbravam esta solução. No entanto, em 1831, em meio às disputas entre grupos políticos que apresentavam leituras diversas do constitucionalismo, a crença da recolonização voltou a circular no Brasil, o que nos sugere como as incertezas trazidas pela Revolução do Porto ainda estavam vivas naquela sociedade.

Assim, em 1831, diversos setores da sociedade carioca passaram a acreditar fortemente, às vésperas da Abdicação, nos rumores, nas teorias conspiratórias e nos relatos diversos que podem ser sistematizados em duas "narrativas" complementares - a de que Portugal pretendia recolonizar o Brasil e a de que D. Pedro I era "antinacional". Dessa maneira, o objetivo principal deste artigo é analisar a disseminação dessas narrativas, avaliando em que medida e de que maneira elas geraram comportamentos que contribuíram para a Abdicação de D. Pedro I.

Utilizo o termo "narrativa" como proposto por Robert Shiller em seu livro Narrative Economics ${ }^{2}$, que a define como uma forma particular de história que mistura fatos, emoções e interesses humanos. Shiller aponta como as narrativas podem se tornar virais como resultado de detalhes arbitrários, como a frequência de contatos entre as pessoas e a forma como elas se conectam a narrativas pré-existentes. Rumores, teorias conspiratórias e até músicas podem ser entendidos como narrativas. Tais insights se somam aos fornecidos pela literatura sobre a disseminação de rumores, que sistematiza seus aspectos principais, como o de serem relatos não apoiados em evidências seguras e

\footnotetext{
${ }^{1}$ Neste contexto o termo "antinacional" refere-se à construção, ainda muito incipiente, de uma identidade nacional brasileira que se contrapunha ao português. Este é, portanto, um momento importante de redefinição dos termos "pátria" e "nação" que, antes da emancipação política do Brasil, eram predominantemente relacionados às identidades regionais como paulistas, pernambucanos e baianenses. JANCSÓ, István; PIMENTA, João P.G. Peça de um mosaico (apontamentos para o estudo da emergência da identidade nacional brasileira). In: MOTA, Carlos Guilherme (Org.). Viagem Incompleta: a experiência brasileira (1500-2000) São Paulo: SENAC, v. 1, p.129-175, 2000.

2 O termo "narrativa" empregado pelo autor não se refere aos aspectos metodológicos das narrativas acadêmicas. SHILLER, Robert J. Narrative economics: how stories go viral and drive major economics events. New Jersey: Princeton University Press, 2019. Em 2013 Shilller foi laureado com o Prêmio Nobel de Economia.
} 
REVISTA ÁG으A, v. 31, n. 3, e-2020310307, 2020, ISSN: 1980-0096

que se disseminam em contextos marcados por ambiguidades, perigos ou hostilidades, ajudando as pessoas a conferir sentido ao seu cotidiano e a lidar com os riscos que enfrentam ${ }^{3}$.

Focalizo neste artigo as "narrativas públicas", ou seja, as que são amplamente disseminadas na "esfera pública" de uma sociedade, isto é, em um espaço conceitual ocupado por mediadores, principalmente os jornalistas, ao final do século XVIII ${ }^{4}$. Nesse contexto político - de presença substantiva de uma esfera pública - o governante está sujeito ao escrutínio público e, por isso, ela tem o papel de contrabalançar o poder político. No Brasil, pode-se identificar o fortalecimento da esfera pública a partir das décadas de 1820 e 1830 com o aumento considerável do número de jornais em circulação no Rio de Janeiro e em outras cidades brasileiras. Diferentemente da acepção de Habermas, onde a esfera pública é ocupada por interlocutores independentes e iguais ${ }^{5}$, entretanto, no Brasil dos oitocentos havia uma ampla presença de jornalistas que também eram políticos, o que não inviabilizou a manifestação de demandas da sociedade civil na esfera pública, dado que os jornalistas e/ou políticos representavam grupos diversos da sociedade.

No que se refere à historiografia da Abdicação, especificamente, estudos mais recentes têm reconstituído o processo pelo qual se manifestavam as mais diversas demandas das elites políticas, das camadas médias e dos estratos mais populares e que, de alguma maneira, contribuíram para o processo de deslegitimação política que levou à Abdicação de D. Pedro I ${ }^{6}$. O porquê desses grupos terem conseguido, em tempo tão curto, levar D. Pedro a abdicar é a questão que pretendemos contribuir para responder.

$\mathrm{O}$ artigo está organizado em três tópicos. O primeiro introduz o novo mundo político constitucional do Primeiro Reinado. O segundo analisa a importância de duas narrativas - a da recolonização e a do Imperador antinacional - para entender a

\footnotetext{
${ }^{3}$ Para trabalhos importantes na historiografia ver: LEFEBVRE, Georges. O Grande Medo de 1789. Rio de Janeiro: Campus, 1979; FARGE, Arlette. Subversive Words: public opinion in Eighteenth-century France. Pennsylvania State University Press, 1994. Para trabalho recente ver: TACKETT, Timothy. Rumor and Revolution: the case of the September Massacres. French History \& Civilization, v. 4, 2011. Para trabalho recente na historiografia do oitocentos ver: PANDOLFI, Fernanda C. Rumores e política no Rio de Janeiro e em Minas Gerais no final do Primeiro Reinado. História (São Paulo), Franca, v. 33, n. 2, p. 307-322. 2014.

${ }^{4}$ HABERMAS, Jürgen. Mudança estrutural na esfera pública. Rio de Janeiro: Tempo Brasileiro, 1984.

${ }^{5}$ Para a crítica do acesso universal e da igualdade na esfera pública ver ELLEY, Geoff. Nations, publics and political cultures: placing Habermas in nineteenth century. In: CALHOUN, Craig (ed.). Habermas and the public sphere. London: MIT Press, 1992, p.289-339. ${ }^{6}$ Ver RIBEIRO, Gladys S. A liberdade em construção: identidade nacional e conflitos antilusitanos no primeiro reinado. Rio de Janeiro: RelumeDumará/FAPERJ, 2002; BASILE, Marcello. Ezequiel Corrêa dos Santos: um jacobino na corte imperial. Rio de Janeiro: FGV, 2001; MOREL, Marco. As transformações dos espaços públicos: imprensa, atores políticos e sociabilidade na cidade imperial (1820-1840). São Paulo: Hucitec, 2005; PANDOLFI, Fernanda C. Política, imprensa e a participação dos militares na Abdicação de Dom Pedro I. História Unisinos, São Leopoldo (RS), v.16, n.3, 2012, p.283-293.
} 
REVISTA ÁG으A, v. 31, n. 3, e-2020310307, 2020, ISSN: 1980-0096

Abdicação. O último aponta como conclusão o fato de que narrativas afetam a realidade política porque contêm elementos de auto-realização - isto é, produzem fatos objetivos que afetam o mundo real - e discute o impacto disso para a Abdicação.

\section{PEDRO I: O IMPERADOR CONSTITUCIONAL}

Com o fim da censura prévia em Portugal e estendida ao Brasil em agosto de 1821, aumentou consideravelmente o número de jornais no Rio de Janeiro ${ }^{7}$. Nesse momento há o surgimento de uma coletivização do político, pois os acontecimentos tornavam-se públicos pela imprensa e pela discussão em novos espaços de sociabilidade como cafés, livrarias, e na maçonaria ${ }^{8}$.

O primeiro semestre de 1821 é caracterizado pelo aparecimento de jornais comportados, cujas propostas eram educar os leitores sobre os preceitos constitucionais que adentravam o Brasil. No segundo do mesmo ano, no entanto, surgiram jornais de perfis diversos, que combatiam o que entendiam como a política de recolonização das Cortes $^{9}$. Esses periódicos debatiam as medidas decretadas por Portugal em relação ao Brasil, que foram consideradas por alguns setores das elites como despóticas e arbitrárias, dado que as Cortes exigiram o retorno de D. Pedro para Portugal e decretaram a criação das Juntas, órgãos administrativos que se ligariam diretamente a Lisboa. Nesse contexto, uma camada numerosa, composta de juristas, burocratas e clérigos que se formou ao redor da Corte do Rio de Janeiro desde 1808, viu suas carreiras comprometidas com a possibilidade da extinção da regência de D. Pedro ${ }^{10}$.

Neste momento, as medidas legais das Cortes portuguesas impostas ao reino do Brasil foram tidas como recolonizadoras. A este respeito, Antonio Rocha aponta que Portugal realmente procurava restabelecer sua supremacia política e comercial, no entanto, não encontrou evidências de que haveria um plano recolonizador ${ }^{11}$. Nesta mesma

\footnotetext{
${ }^{7}$ A instalação da impressa no Brasil data de 1808, com a vinda da família real. O primeiro jornal publicado foi a Gazeta do Rio de Janeiro que, mesmo sendo de cunho oficial, divulgou as ideias iluministas, ainda que para refutar alguns de seus preceitos. MOREL, Marco Os primórdios da imprensa no Brasil. In: MARTINS, A.; LUCA, T. (Org.). História da imprensa no Brasil. São Paulo: contexto, 2012. E-book, Kindle Edition.

${ }^{8}$ NEVES, Lúcia Maria Bastos P. Cidadania e participação política na época da Independência do Brasil. Cadernos Cedes, Campinas, v. 22, n. 58, p. 47-64, dez. 2002.

${ }^{9}$ LUSTOSA, Isabel. Insultos impressos: o nascimento da imprensa no Brasil. In: MALERBA, Jurandir (Org.). A Independência brasileira: novas dimensões. Rio de Janeiro: FGV, 2006, p.245-249.

${ }^{10}$ NEVES, Lúcia Maria Bastos; MACHADO, Humberto Fernandes. Portugueses e brasileiros? In: __. O Império do Brasil. Rio de Janeiro: Nova Fronteira, 1999, p.82-83.

${ }^{11}$ ROCHA, Antonio Penalves. A recolonização do Brasil pelas Cortes: história de uma invenção historiográfica. São Paulo: Editora UNESP, 2008, p.9-21.
} 
REVISTA ÁG으A, v. 31, n. 3, e-2020310307, 2020, ISSN: 1980-0096

linha interpretativa, outros autores consideram que havia uma proposta de centralização em Portugal que na imprensa adquiriu o sentido de restauração do sistema colonial, tendo se disseminado entre grupos políticos importantes ${ }^{12}$.

A atitude de hostilidade da imprensa às Cortes portuguesas, entretanto, não afetou a imagem de D. Pedro, pois mesmo os periódicos mais radicais o consideravam indispensável para a unidade e integridade do País. Em vista disto, em outubro de 1822 D. Pedro I é aclamado nas ruas do Rio de Janeiro e sua imagem é veiculada e reificada através das festas cívicas e da nova simbologia do Brasil independente ${ }^{13}$. Porém, em 1831, a narrativa da recolonização voltou a circular, tendo papel importante na deslegitimação do Imperador, como iremos analisar no próximo tópico.

\section{PEDRO I: O IMPERADOR INCONSTITUCIONAL}

A Carta de 1824, outorgada por D. Pedro I, lançou as diretrizes para a formação de uma monarquia constitucional, como a divisão dos poderes e a adoção de eleições frequentes para deputados, senadores, membros dos Conselhos Gerais das Províncias, vereadores e juízes de paz. Isto gerou novas oportunidades para as camadas médias e outros setores das elites se lançarem na política. Contudo, o processo de implementação da monarquia constitucional foi marcado por muita instabilidade, que se refletia no grau de liberdade de imprensa. No período da Independência, por exemplo, houve considerável liberdade de imprensa. Já entre 1823 e 1824, o número de impressos foi reduzido significativamente devido à intensa perseguição aos jornalistas ${ }^{14}$.

Com o funcionamento do Parlamento em 1826 a pressão por liberdade de imprensa aumentou, sendo este momento considerado o início de um governo representativo, embora os deputados desconfiassem quanto a esta questão ${ }^{15}$. Em decorrência disso, houve uma intensa disputa por espaços de soberania política por parte dos deputados liberais moderados que alavancaram a pauta da liberdade de imprensa ${ }^{16}$.

\footnotetext{
${ }^{12}$ BERBEL, Márcia Regina. A retórica da recolonização. In: JANCSÓ, I. (org.). Independência: história e historiografia. São Paulo: Hucitec, 2005, p.799-804. LUSTOSA, Isabel. Insultos impressos: a guerra dos jornalistas na Independência (1821-1823). São Paulo: Companhia das Letras, 2000.

${ }^{13}$ SOUZA, Iara Lis Carvalho. Pátria coroada: o Brasil como corpo político autônomo (1780-1831). São Paulo: UNESP, 1999.

${ }^{14}$ REIS, Arthur Ferreira. "Anarquistas" e "servis": uma análise dos projetos políticos do ano de 1826 no Rio de Janeiro. Dissertação de mestrado em História, Universidade Federal do Espírito Santo, Vitória, 2016, p.36-63.

${ }_{15}$ CAMPOS, Adriana Pereira. Magistratura eleita: administração política e judicial no Brasil (1826-1841). Almanack, Guarulhos, n. 18, p. 97-138, 2018, p.107-108.

${ }^{16}$ MARQUES JÚNIOR, Nelson Ferreira. O despertar do Império independente: áulicos e a formação de um projeto de Brasil na Corte fluminense (1822-1831). Tese (Doutorado em História), Universidade Federal Rural do Rio de Janeiro, Seropédica (RJ), 2018 , p.14.
} 
REVISTA ÁG으A, v. 31, n. 3, e-2020310307, 2020, ISSN: 1980-0096

O decreto de agosto de 1827 aboliu formalmente a censura, impulsionando o desenvolvimento do periodismo de caráter panfletário e de linguagem violenta que refletia a disputa política ${ }^{17}$. Mas os acontecimentos também contribuíram para a radicalização da linguagem dos jornais, como foi o caso da Noite das Garrafadas.

Antes das Garrafadas a imprensa liberal exaltada, além de discutir suas agendas políticas específicas, recorrentemente lançou mão de uma narrativa - a de que existia um Gabinete Secreto, formado por maus conselheiros contrários aos interesses da nação, que comandava o governo de D. Pedro I. Ao que tudo indica, esse Gabinete nunca existiu. Para Octávio T. de Souza, existiu algo parecido, representado pelos indivíduos de extrema confiança do Imperador, com acesso diário a ele e que não podem ser tidos apenas como criados do Paço. Tais indivíduos haviam se tornado personagens antipáticos e odiosos, como João Carlota, Plácido de Abreu, Rocha Pinto, Francisco Maria Gordilho Veloso de Barbuda (o barão de Pati de Alferes), Visconde de Lorena, e o Marquês de Jacarepaguá, senador do Império. Mas, a figura que parece ter sido mais associada ao Gabinete Secreto trata-se de Francisco Gomes da Silva, o Chalaça ${ }^{18}$.

Após ter sido nomeado a postos importantes, Chalaça tornou-se secretário do Gabinete Imperial. Foi muito elogiada sua eficiência, inteligência, sagacidade e instrução respeitável. Sua fidelidade a D. Pedro I e sua honestidade têm sido mencionadas pelos historiadores, uma vez que ele não teria aproveitado a oportunidade de seu cargo para enriquecer-se. Ele também foi figura controvertida, descrito como: “Janota, irritava pelo arrebique o elemento nacional inclinado à simplicidade e até ao desleixo de maneiras e de traje", sendo por essas características alcunhado de Chalaça ${ }^{19}$. Talvez para desfazer os boatos de existência de um Gabinete Secreto ou pelas pressões do Ministério Barbacena, D. Pedro I afastou Chalaça do Paço, mandando-o para fora do Brasil junto com Rocha Pinto providos de pensões para tratarem de assuntos particulares do Imperador.

A alusão ao Gabinete Secreto, segundo Helio Vianna, surgiu da parte do marquês de Barbacena quando em conflito com D. Pedro I por causa de sua demissão do cargo de Ministro da Fazenda em 1830. Ele foi demitido em meio a polêmicas envolvendo suas

NUNES, Tassia Toffoli. Liberdade de imprensa no Império brasileiro: os debates parlamentares (1820-1840). Dissertação (Mestrado em História), Universidade de São Paulo, São Paulo, 2010, p.50-60.

${ }^{17}$ SODRÉ, Nelson Werneck. História da imprensa no Brasil. Rio de janeiro: Civilização Brasileira, 1966, p.97.

${ }^{18}$ Sobre a relação de Chalaça com o Gabinete Secreto, coloca Octavio Sousa: "o homem realmente de mais qualidades do 'gabinete secreto', talvez a sua mais autêntica encarnação". SOUSA, Octavio Tarquínio de. História dos fundadores do Império do Brasil: a vida de d. Pedro I. Rio de Janeiro: José Olympio, 1957. v. 4, p.842.

${ }^{19}$ SOUSA, 1957. v. 4, p.842. 
REVISTA ÁG으A, v. 31, n. 3, e-2020310307, 2020, ISSN: 1980-0096

contas relativas às despesas gastas com sua missão na Europa em 1828 e 1829, que incluem a despesas com a viagem da jovem rainha de Portugal à Inglaterra e com o segundo casamento do Imperador. As dúvidas quanto aos gastos de Barbacena nesta missão repercutiram na imprensa, tendo o próprio Barbacena se manifestado publicamente em defesa de sua honra, referindo-se à existência de "conselheiros secretos" que cercavam o Imperador ${ }^{20}$. De acordo com Hélio Vianna ${ }^{21}$, era a primeira vez que um eminente político fazia tal acusação. D. Pedro I também se manifestou, acusando Barbacena por desvio de dinheiro nas contas relativas às suas missões na Europa. Embora almejasse passar a imagem de zelo com as contas públicas, o Imperador acabou sendo criticado na imprensa por autorizar gastos sem a consulta e o consentimento do Parlamento e por financiar portugueses na luta contra D. Miguel, o que contribuiu para desgastar politicamente seu governo ${ }^{22}$.

A narrativa da existência de um gabinete secreto, até então, ficou mais restrita aos debates na imprensa. Contudo, após a Noite das Garrafadas, ela se uniu a outras duas narrativas - a do Imperador antinacional e a da recolonização do Brasil -, sendo todas elas amplamente disseminadas tanto pela imprensa liberal moderada como pela exaltada. Nesse sentido, a crítica ao governo pelo importante jornal liberal moderado Aurora Fluminense $^{23}$ tornou-se mais radical com a incorporação do tema do antilusitanismo em seu discurso. Essa mudança, portanto, contrasta bastante com sua posição anterior, cujas críticas mais contundentes eram feitas principalmente aos ministros, poupando o Imperador.

É importante sublinhar que a Noite das Garrafadas refere-se a uma série de conflitos que se estendeu de 11 a 15 de março de 1831 pelas ruas do Rio de Janeiro. Eles se iniciaram em meio aos festejos organizados pelos "portugueses" com fogueiras e fogos de artifício nos quadriláteros delimitados pelas Ruas da Quitanda, dos Ourives, Direita e das Violas, para comemorar a volta do Imperador de sua viagem à província de Minas

\footnotetext{
${ }^{20}$ Ver "A Exposição do Marquês de Barbacena", publicada em VIANNA, Hélio. D. Pedro I e D. Pedro II. Rio de Janeiro: Nacional, 1966, p.83.

21 VIANNA, 1966, p.88

${ }^{22}$ CUPELLO, Rafael. "Tradicionalistas" x “Conservadores": uma disputa palaciana na Corte de D. Pedro I. In: CAMPOS, Adriana Pereira; RIBEIRO, Geisa Lourenço; SIQUEIRA, Karulliny Silverol; MOTTA, Katia Sausen da (Org.). Entre as províncias e a nação: os diversos significados da política no Brasil do Oitocentos. Vitória: Editora Milfontes, 2019, p.65-67.

${ }^{23}$ O Aurora Fluminense circulou de 1827 a 1835, em geral três vezes por semana. Evaristo da Veiga foi o principal redator a partir de 1829 e um representante importante do grupo liberal moderado. ANDRADE, Marcos Ferreira de \& SILVA, Janaína de Carvalho. Moderados, exaltados e caramurus no prelo carioca: os embates e as representações de Evaristo Ferreira da Veiga (1831-1835). Almanack, Guarulhos, n. 4, 2012, p.132-134. O liberalismo moderado pautava-se pela defesa do Legislativo e da Constituição, cujos reformas, quando necessárias, deveriam pautar-se pela moderação.
} 
REVISTA ÁG으A, v. 31, n. 3, e-2020310307, 2020, ISSN: 1980-0096

Gerais. Nessas ruas, segundo os relatos, os conflitos ocorrem entre "portugueses" e "brasileiros", que se insultavam mutuamente, sendo que os portugueses davam vivas ao Imperador, aos "bons portugueses" e "morras" aos "republicanos"; e os brasileiros davam vivas à "federação". Das janelas das casas eram arremessados, entre outras coisas, cacos de vidros de garrafas $^{24}$.

Embora a Aurora Fluminense acusasse os portugueses de agredir os brasileiros na Noite das Garrafadas com cacos de garrafa, cacetes e até tiros de pistola, advertia que não se referia a todos os portugueses, mas apenas àqueles que vieram para o Brasil depois da proclamação da Independência e que, por isso, não pertenciam à nossa associação política $^{25}$. O comportamento agressivo dos portugueses, segundo este jornal, contou com a conivência do governo que, por exemplo, confiscou somente as armas ou paus dos indivíduos que pareciam ser brasileiros, enquanto os demais praticavam impunemente todo tipo de violência.

As fontes indicam a presença de conflitos antilusitanos nas Garrafadas, que podem ser remetidos às disputas no mercado de trabalho entre os homens pobres, isto é, entre portugueses versus escravos e libertos que exerciam o mesmo ofício ${ }^{26}$. Mas igualmente importante foi a população ter passado a atribuir o agravamento da situação econômica gerada pela crise de abastecimento de alimentos em 1831 à ganância dos comerciantes portugueses $^{27}$. No entanto, deve-se considerar uma amplitude maior de motivações a seus participantes, pois tanto os depoimentos das testemunhas inquiridas no Traslado das Garrafadas $^{28}$, quanto os relatos na imprensa relatam a presença das elites políticas, camadas médias e militares nos eventos, tema que ainda carece de mais estudos.

Nesse sentido, é importante ressaltar que brasileiros e portugueses eram identidades intercambiáveis e carregadas de conteúdo político. Isto pode ser observado na Carta de 1824, que considerou como brasileiros todos os portugueses que

\footnotetext{
${ }^{24}$ PANDOLFI, Fernanda Cláudia. A abdicação de D. Pedro I: espaço público da política e opinião pública no final do Primeiro Reinado. Tese (Doutorado em História), Universidade Estadual Paulista, Assis, 2007, p.48-49.

${ }^{25}$ Aurora Fluminense, 16 de março de 1831.

${ }^{26}$ KARASCH, Mary C. A vida dos escravos no Rio de Janeiro (1808-1850). São Paulo: Companhia das Letras, 2000.

${ }^{27}$ LENHARO, Alcir. As tropas da moderação: o abastecimento da Corte na formação política do Brasil (1808-1842). São Paulo: Símbolo, 1979.

${ }^{28}$ Traslado do processo a que deu motivo os tumultos das Garrafadas do dia 13, 14 e 15 de março de 1831 (p. 1-31). Este documento contém depoimentos de policiais e de militares, como também de moradores das ruas que presenciaram os conflitos ou participaram deles. Este documento apresenta algumas subdivisões: 1) Depoimentos de policiais e militares (p. 1-16); 2) "Inquirição de testemunhas para corpo de delito indireto" (p. 16-20); 3) Sentença de julgamento e corpo de delito (23 de março de 1831) (p. 20-26); 4) Pronúncias (p. 26-31).
} 
REVISTA ÁG으A, v. 31, n. 3, e-2020310307, 2020, ISSN: 1980-0096

permaneceram no Brasil após a Independência ${ }^{29}$. Também, Robert Rowland ${ }^{30}$ aponta que na Corte e no Sudeste o "partido português" era formado pelos que apoiavam o projeto centralizador de D. Pedro I, sendo constituído sobretudo por mercadores e comerciantes de origem portuguesa. Os contrários a este grupo eram identificados como defensores da causa do Brasil. Já Gladys Ribeiro ressalta que "ser português" e "ser brasileiro" são menos termos ligados à pátria, do que construções que envolvem formas de participação política e concorrência entre grupos por direitos ou mesmo privilégios econômicos ${ }^{31}$. Por exemplo, a autora mostra como os homens de cor, em suas disputas com os portugueses por espaço no mercado de trabalho, identificavam suas pautas como "causa do Brasil" e "amor à pátria"32.

Os jornais Republico ${ }^{33}$ e Tribuno do Povo ${ }^{34}$, ambos de vertente liberal exaltada, se diferenciavam dos liberais moderados por empregarem uma linguagem mais incisiva na crítica ao governo de D. Pedro I e por defenderam o federalismo que, em termos gerais, significava a ampliação dos poderes políticos das províncias. Além disso, a maioria dos redatores não ocupava espaços formais na política ou possuía posições inferiores na estrutura de poder político. Mesmo esses críticos mais radicais tentavam cooptar o Imperador para atender suas demandas.

Entretanto, o tom de crítica ao governo tornou-se mais virulento e extremado após as Garrafadas. Por exemplo, dois dias antes o Republico havia criticado o não-respeito à Constituição acusando o governo de ser guiado por um Gabinete Secreto de homens ferozes. Embora enfatizando o respeito aos agentes da administração, defendia que ele desapareceria quando os mesmos se tornassem despóticos. Como exemplo de ato despótico, o redator citou a dissolução da Assembleia Constituinte (O Republico, no 45 09/03/1831, p.204-205). Portanto, neste e em outros números anteriores, a crítica do Republico ao governo ainda não havia incorporado o antilusitanismo. Mas a partir do

\footnotetext{
${ }^{29}$ Ver item $4^{\circ}$ do Art. $6^{\circ}$ "São cidadãos brasileiros" da Constituição Política do Império do Brasil. Disponível em: www.planalto.gov.br/ccivil_03/constituição/Constituição24.htm.

${ }^{30}$ ROWLAND, Robert. Patriotismo, povo e ódio aos portugueses: notas sobre a construção da identidade nacional no Brasil independente. In: JANCSÓ, Instván (Org.). Brasil: formação do Estado e da nação. São Paulo: Hucitec, 2003 , p.372.

${ }^{31}$ RIBEIRO, 2002. Ver Capítulo 1, p.27-142.

${ }^{32}$ RIBEIRO, 2002, p.215-216.

${ }^{33} \mathrm{O}$ primeiro número do Republico data de 2 de outubro de 1830 . O redator era Antônio Borges da Fonseca. Nasceu na Paraíba em 7 de abril de 1808 descendendo de importante família de administradores coloniais. Aos 18 anos foi para Recife estudar no Liceu Pernambucano e conviveu com nomes do jornalismo de destaque da Revolução Pernambucana de 1817 e da Confederação do Equador de 1824. Participou da Praieira no Recife em 1848-1849 representando os segmentos mais populares. Ocupou vários cargos públicos e foi redator de diversos periódicos ao longo de sua vida. PANDOLFI, 2012, p.287.

34 Este jornal foi publicado entre 18 de dezembro de 1830 e 6 de março de 1832, tendo como redator Francisco das Chagas Oliveira França, natural de Minas Gerais. Participou das Garrafadas e do "7 de abril”. PANDOLFI, Fernanda C. O papel da imprensa na política no final do Primeiro Reinado: uma análise do jornal Tribuno do Povo. História e Cultura, Franca, v.3, n.3, 2014 , p.329.
} 
REVISTA ÁG요A, v. 31, n. 3, e-2020310307, 2020, ISSN: 1980-0096

número do dia 16 de março de 1831, em que pela primeira vez a Noite das Garrafadas foi abordada, o discurso de oposição ao governo se radicaliza:

É desta forma, Brasileiros, que somos agredidos e agredidos atraiçoadamente pela gente xumbatica? E dir-se-á que a provoquemos? Ah! Malvados, que, acobertados pelo infame gabinete secreto, assim derramais o sangue brasileiro que pede vingança! (O Republico, $\mathrm{n}^{\circ} 47$ - 16/03/1831, p.217).

A ideia de que portugueses subjugavam os brasileiros era cada vez mais disseminada. Em uma matéria do Republico, o autor afirmou que era brasileiro, inclusive justificando que era nascido e educado no Brasil, numa interpretação incomum na época e mais estrita do "ser brasileiro" por escolha, isto é, por amor a pátria. Nesse sentido coloca: “[...] um português é um português [...]. Honra lhes seja dada; adora sua Pátria, e por isso entendem que tudo deve sacrificar por ela". Por fim conclamou pela reação dos brasileiros "enxovalhados" pelos portugueses". 35

Da mesma forma, o jornal Tribuno do Povo usou a carta de um leitor para convencer os brasileiros do perigo da dominação portuguesa. O tema central é a vingança dos sicilianos contra seus conquistadores franceses no século XVIII. A história descrita é que, cansados de serem ultrajados, os sicilianos executaram com êxito, em apenas duas horas, o plano de que cada siciliano ficaria a cargo de assassinar um francês. O leitor procura justificar a necessidade deste ato violento que, em sua opinião, livrou a Sicília de seus "opressores", pois os que não foram mortos, cerca de 300 ou 400 franceses, refugiaram-se no forte de "Sperlingue" e morreram vitimados pela fome. A situação dos sicilianos é comparada a dos brasileiros que, segundo o mesmo, sofriam com a deslealdade dos portugueses que pacificamente foram acolhidos no solo brasileiro. Apesar de ter considerado o plano arriscado, justificou-o pela epígrafe - "Mais vale morrer livre, do que viver escravo". (CORRESPONDÊNCIA. O Tribuno do Povo, $n^{\circ} 23$ $-21 / 03 / 1831$, p.102) ${ }^{36}$.

Em número posterior do Tribuno do Povo, talvez por ter suscitado críticas a forma violenta de vingança que sugeriu aos brasileiros, o redator considerou que os meios

\footnotetext{
${ }^{35}$ Artigo Comunicado. O Republico, n ${ }^{\circ} 49-25 / 03 / 1831$, p.227-229

${ }^{36}$ Correspondência assinada por S.M.
} 
REVISTA ÁG으A, v. 31, n. 3, e-2020310307, 2020, ISSN: 1980-0096

usados pelos sicilianos para se libertarem dos franceses não convêm ao Brasil, pois, em sua opinião, os sicilianos lutavam com homens de honra e não com "homens sem honra", como essa "horda vil de covardes lusitanos" que mereciam ser debelados com o desprezo. Por fim, defendeu que os brasileiros não deveriam sujar as mãos com sangue lusitano, mas que deixassem os portugueses entregues a nulidade. ${ }^{37}$

A narrativa que rotulava o Imperador como antinacional dava cada vez mais ênfase à uma ampla e generalizada suposta conspiração dos portugueses contra os brasileiros, que figurava nas páginas dos jornais. A linguagem empregada tornava-se também cada vez mais extremada. O Tribuno do Povo, por exemplo, justificou o uso de uma "linguagem decisiva" para denunciar os "portugueses traidores" os quais, em sua opinião, eram protegidos pelo governo e pelo Gabinete Secreto:

Quando o Governo protege os lusitanos nossos inimigos; quando os Brasileiros são massacrados só nos resta lançar mão desta linguagem decisiva; se morramos, morramos com honra sustentando O SAGRADO JURAMENTO, QUE, PERANTE DEOS TODOS NÓS MUI VOLUTARIAMENTE PRESTAMOS, e que só tem sido violado pelos traidores de alto coturno que são lá Presidentes do Gabinete Secreto [...]. ${ }^{38}$

Cartas de leitores que apresentavam D. Pedro I como protetor dos portugueses contribuíam para divulgar essa interpretação para um público cada vez mais amplo, fazendo uso de histórias de povos subjugados e de teorias conspiratórias. $\mathrm{Na}$ carta assinada por "Brasileiro Livre", por exemplo, o governo é apresentado como traidor que agia, por intermédio do Gabinete Secreto, para conspirar contra o Brasil. Quanto ao Imperador, ele foi acusado de compactuar com tais ações, dado que nenhuma satisfação teria dado à nação, ilustrando esta posição com o seguinte ditado: "quem cala consente". Ao longo da carta, o autor erigiu a imagem de D. Pedro como defensor dos portugueses, como fica explícita na citação:

\footnotetext{
${ }^{37}$ O Tribuno do Povo, ${ }^{\circ} 25-28 / 03 / 1831, \mathrm{p} .110$.

${ }_{38}$ O Tribuno do Povo, $\mathrm{n}^{\circ} 25-28 / 03 / 1831, \mathrm{p} .108-109$
} 
REVISTA ÁG으A, v. 31, n. 3, e-2020310307, 2020, ISSN: 1980-0096

A Nação Brasileira tem-se doído dessas preferências, e com razão diz que ela elegeu V.M. para ser Imperador dos Brasileiros, e não dos Portugueses; estamos no Brasil, e é preciso ceder a Opinião Pública" (Carta Segunda, que sobre os negócios do desventurado Brasil, dirige a S. M. I. e C. o Brasileiro Livre. ${ }^{39}$

A partir da Noite das Garrafadas, portanto, o conflito político configurava-se cada vez mais numa luta de brasileiros versus portugueses, reunindo grupos diversos como liberais moderados, liberais exaltados e outros segmentos em torno da causa nacional.

Mas nem toda a imprensa era de oposição, e os apoiadores do governo de D. Pedro I também se preocupavam em moldar a opinião pública ${ }^{40}$, a fim de fornecer sustentação ao governo de D Pedro I. Esse grupo de áulicos ocupava posições diversas no Legislativo, na imprensa e, em especial, no Senado e no Executivo. A vertente política que os unia era a do conservadorismo liberal, adepta dos postulados liberais como o constitucionalismo, a divisão dos poderes e a representação política. Diferenciavam-se dos demais grupos pela defesa de uma monarquia constitucional centralizada, cuja soberania residia no rei, em seu papel de justo equilíbrio, e não no parlamento. Os áulicos não eram tão minoritários como as vezes se pensa, dos 69 periódicos publicados ao longo do Primeiro Reinado, 21 eram de tendência política áulica, o que significa quase 30\%, podendo ser ainda maior se forem selecionados somente os jornais políticos ${ }^{41}$.

O jornal Novo Censor ${ }^{42}$, de linha política áulica, sobressaiu-se pela intensa crítica aos jornais Republico e Tribuno do Povo. Para o Novo Censor, o aumento do número de

\footnotetext{
${ }^{39}$ O Tribuno do Povo, $\mathrm{n}^{\circ} 26$ - 31/03/1831, p.111-116.

${ }^{40}$ A opinião deixava de significar apenas um juízo sobre algo e se constituía em uma esfera da crítica que era usada como recurso da legitimação de práticas políticas. É interessante notar que neste contexto as opiniões individuais ou setoriais eram apresentadas como opinião geral. MOREL, Marco. As transformações dos espaços públicos: imprensa, atores políticos e sociabilidade na cidade imperial (1820-1840). São Paulo: Hucitec, 2005, p.200-213. NEVES, Lúcia Bastos Pereira das. Opinión Pública. In: FERNÁNDEZ SEBASTIÁN, Javier (dir.). Diccionario político y social del mundo iberoamericano: la era de las revoluciones, 1750-1850. Madrid: Fundación Carolina, 2009, p. 1012-1014. Como coloca Bernard Manin, a opinião pública refere-se a opinião de uma parcela da população que se organizava, por exemplo, em partidos e jornais. A reunião dos agentes, antes dispersos, ampliou o alcance de suas demandas. MANIN, Bernard. Los princípios del gobierno representativo. Madrid: Alianza Editorial, 1998, p.210-211.

${ }^{41}$ MARQUES JÚNIOR, Nelson. O despertar do Império independente: áulicos e a formação de um projeto de Brasil na Corte fluminense (1822-1831). Tese de Doutorado em História, Universidade Federal Rural do Rio de Janeiro, Seropédica (RJ), 2018, p.113117.

42 O nome completo é: O Novo Censor. Jornal Analytico. Era impresso pela Tipografia de Gueffier e C., na Rua da Quitanda, n.79. Além da informação de ser um jornal governista, não foi encontrado mais nada sobre este jornal nos manuais de história da imprensa. Ver, por exemplo, VIANNA, Helio. Contribuição à história da imprensa brasileira (1812-1869). Rio de Janeiro: Imprensa Nacional, 1945, p.130. Em trabalho recente sobre os periódicos áulicos do Primeiro Reino, o redator ainda consta como desconhecido; ver MARQUES JÚNIOR, 2018, p. 229. Há 12 números deste jornal - de 5 de fevereiro a 30 de março de 1831, mas falta 1. Os quatro primeiros números atualmente estão disponíveis na hemeroteca da Biblioteca Nacional. Os demais, publicados depois de 26/02/1831, podem ser encontrados em Periódicos Raros da Biblioteca Nacional - PR-SOR 00323 [1]. Como a consulta do jornal foi realizada no setor de periódicos raros da Biblioteca Nacional e anotadas pela data de publicação, não foi possível indicar a edição a partir do $\mathrm{n}^{\circ} 05$.
} 
REVISTA ÁG으A, v. 31, n. 3, e-2020310307, 2020, ISSN: 1980-0096

escritores públicos que se colocavam como defensores dos direitos individuais, da liberdade e da independência nacional, deveria acarretar uma marcha segura rumo à civilização e contribuir para o desenvolvimento da indústria. No entanto, argumenta que ocorre o contrário, pois esses escritores não estão empenhados em avivar os elementos de uma verdadeira política baseada na moral, na religião e nos deveres para com o príncipe. Nesse sentido, considera que a política se tornou uma odiosa confusão de "vergonhosas disputas nominais, guerras de palavras indefinidas, e embrulhada na equivocidade, tediosas, ridículas desavenças, indiscretas, palpáveis contradições, sonhos, aleivosias, intrigas, improvadas acusações [...]".43

O Novo Censor considerava ser necessário desmascarar estes maníacos que inquietavam a sociedade, em referência aos redatores dos periódicos liberais. Valiase da Constituição para defender a repressão que o Imperador deveria exercer sobre esses escritores, uma vez que considera que ao Imperador foi dado o poder de velar para a manutenção da Independência, equilíbrio e harmonia dos poderes políticos ${ }^{44}$. Colocavase como um constitucional, afirmando inclusive que os constitucionais não podem ser espectadores ociosos de doutrinas "anti-sociais". Criticou os periódicos liberais, em especial o Tribuno do Povo, por pregarem a existência de um Gabinete Secreto, o que considerava uma injúria para a excitar a rebelião contra a sagrada pessoa do Imperador. Para o Novo Censor, esses escritores, que "a torto e a direito" gritavam contra o despotismo e ostentavam patriotismo, transtornavam a base do Contrato Social, pois espalhavam entre os cidadãos a anarquia, a confusão, a desgraça e a desunião (O Novo Censor, $\mathrm{n}^{\circ} 01-05 / 02 / 1831$, p.2-3).

O Novo Censor acusou o jornal Tribuno do Povo de ter lançado uma conspiração, que consistia no boato generalizado que Chalaça e Luiz do Rego teriam sido convidados pelo Gabinete Secreto para executar um plano contra a Independência e a Constituição. Criticou, ironicamente, este boato, considerando-o um disparate:

Porventura um criado do Monarca, um Francisco Gomes, é algum herói que por suas ações gloriosas, por suas vitórias, por seus talentos, avulte a ponto de assombrar os nossos espíritos? Quem chamado a ver um tal aborto

\footnotetext{
${ }^{43}$ O Novo Censor, $\mathrm{n}^{\circ} 01-05 / 02 / 1831, \mathrm{p} .1$.

${ }^{44}$ O Novo Censor, $\mathrm{n}^{\circ} 01-05 / 02 / 1831$, p.2. O redator cita o Título 5. ${ }^{\circ}$ da Constituição do Império, Cap. 10.
} 
de demência, deixará de rir-se? Mas não, Brasileiros. O Tribuno conhece o disparate de tal ideia. ${ }^{45}$

O Novo Censor acusou o Republico e o Tribuno de espalharem o ódio contra os empregados públicos e enfraquecerem o governo para apoderarem-se de todas as repartições, de serem separatistas, de desejarem retalhar a pátria para colocar nas províncias os seus "Caciques". ${ }^{46}$ Em sua opinião, o Tribuno iludia os incautos com a sonhada existência do Gabinete Secreto, difamando as ações do governo e ofendendo a reputação do Imperador. ${ }^{47}$ Ainda, alegou ignorar quem são os membros do Gabinete Secreto e, ironicamente, indagou que se eles se encontrassem na Quinta da Boa Vista como mencionado pelo Tribuno, Republico e Aurora, não seria secreto, como assim sustentavam estes denunciantes. ${ }^{48}$

Embora também houvesse jornais que defendiam o governo, eles não conseguiram aglutinar as demandas políticas e insatisfações. A balança, portanto, acabou pendendo a favor dos opositores de D. Pedro, o que revela não somente a capacidade de articulação política dos liberais no Parlamento e na imprensa, mas também a força de suas narrativas em agregar grupos diversos em torno de uma causa.

Na própria imprensa é possível identificar que tais narrativas acabavam gerando comportamentos que contribuíam para confirmá-las. O jornal Aurora Fluminense, por exemplo, denunciou que muitos compatriotas tinham sido espancados a pretexto de serem federalistas, questão essa que, na opinião do jornal, deveria ser resolvida por deliberação do Parlamento. O exemplo mencionado é o de um estudante que foi atacado fisicamente por dois homens, sendo que um deles arrancou o seu chapéu verde e amarelo, pelo simples fato deste chapéu ser o símbolo da federação. O jovem tentou resistir, no entanto, segundo a Aurora, foi atacado com uma pancada sobre o peito, e, ao perguntarem ao ferido sobre os agressores, este teria dito "que seria inútil dizê-lo; que ele era Brasileiro, e isso bastava para que o assassino não houvesse de ser punido; que o seu sangue ou tarde ou cedo seria vingado por seus patrícios". ${ }^{49} \mathrm{O}$ fato de um jornal liberal moderado como a Aurora

\footnotetext{
${ }^{45}$ O Novo Censor, $\mathrm{n}^{\mathrm{o}} 2-12 / 02 / 1831, \mathrm{p} .3$.

46 O Novo Censor, 09/03/1831, p.1.

47 O Novo Censor, 05/03/1831, p.2.

${ }^{48}$ O Novo Censor, 12/03/1831, p.2.

${ }^{49}$ Aurora Fluminense, n ${ }^{\circ} 463-18 / 03 / 1831$, p.1953-1955.
} 
REVISTA ÁG으A, v. 31, n. 3, e-2020310307, 2020, ISSN: 1980-0096

Fluminense denunciar as agressões que envolviam os adeptos do federalismo ${ }^{50}$, entretanto, não significa que o jornal apoiasse esta agenda, defendida pelos liberais exaltados. Seu objetivo era, ao que tudo indica, divulgar a união, mostrando a necessidade de aplainar diferenças para combater o que chamavam de ultrajes portugueses feitos a nação.

Um outro exemplo nesse sentido foi o relato da Aurora Fluminense de uma cerimônia solene da entrada do Imperador, onde os integrantes da comitiva a cavalo ameaçavam os cidadãos com chicote se não gritassem viva o Imperador, morra $o$ Republico, numa a referência ao redator do jornal liberal exaltado Borges da Fonseca. ${ }^{51}$ Estes exemplos sugerem um esforço dos liberais moderados em deixar as diferenças de lado, unindo forças com outros grupos políticos com capilaridade na sociedade para pressionar o governo.

Buscava-se além disso mobilizar a sociedade de forma mais ampla, atribuindo comportamento discriminatórios, em termo raciais, aos portugueses. Segundo a Aurora, eram constantes as agressões verbais aos brasileiros, pois constantemente se ouviam pelas lojas em matar cabras, ensinar bodes e outras expressões quando passava um brasileiro e que, além disso, os habitantes da Rua do Comércio estavam armados com pistolas, espingardas e espadas para repelir os filhos da pátria. ${ }^{52}$

As fontes sugerem, assim, que as narrativas estimulavam agressões físicas e verbais entre portugueses e brasileiros e, neste sentido, acabavam se autoconfirmando, ainda que não se possa descartar que tais conflitos fossem também incentivados, por meio da imprensa, por aqueles que deles procuravam se beneficiar. Pode se afirmar, portanto, que a Aurora Fluminense passou a dar uma dimensão nacional e partidária aos conflitos antilusitanos, pois neste momento não era somente uma questão de maus ministros e maus conselheiros que prejudicavam o governo, mas toda uma nação era ultrajada pelos portugueses.

\footnotetext{
${ }^{50}$ A pauta principal do federalismo neste momento era a defesa de mais autonomia para as províncias gerirem a justiça e a economia internas, não sendo intrinsecamente incompatível com a monarquia constitucional. COSER, Ivo. O conceito de federalismo e a ideia de interesse no Brasil no século XIX. Dados. Rio de Janeiro, v.51, n.4, 2008, p.946-948.

${ }^{51}$ Aurora Fluminense, no 463 - 18/03/1831, p.1953-1955.

${ }^{52}$ Aurora Fluminense, no 463 - 18/03/1831, p.1953-1955.
} 
REVISTA ÁG으A, v. 31, n. 3, e-2020310307, 2020, ISSN: 1980-0096

No pasquim Os Dois Compadres Liberais ${ }^{53}$ pode-se extrair mais indícios sobre os motivos que levaram as pessoas a acreditarem na recolonização do Brasil. Publicado treze dias após a Abdicação, esse pasquim foi escrito no calor dos acontecimentos. Na coluna intitulada "Sessão dos Dois Compadre liberais", que continuava nos demais exemplares, o redator afirmou ter transcrito o diálogo de dois compadres, os quais chamou de Brasileiro e Europeu. Este é um exemplo de como muitas características da imprensa vintista cristalizaram-se como estilos, como forma de diálogo entre iguais e pedagogia cívica, ambos com objetivo de divulgar o constitucionalismo moderno para um público mais amplo ${ }^{54}$.

O "compadre" Europeu, por exemplo, acusou o redator do jornal Brasileiro Imparcial de ter disseminado a intriga entre os brasileiros natos e os brasileiros adotivos ${ }^{55}$, levando os brasileiros a suspeitarem da recolonização e os adotivos a suspeitarem de sua expulsão do território brasileiro. ${ }^{56}$ Com posição contrária, o "compadre" Brasileiro respondeu ao Europeu que acreditava na recolonização do Brasil pelos portugueses e que, por isso, defendia que os "pés-de-chumbo", numa referência pejorativa aos portugueses, deveriam ser expulsos do Brasil para que a tranquilidade reinasse. O Europeu argumentou que essa expulsão era contrária ao "direito das gentes" e perguntou ao compadre Brasileiro quem são os pés-de-chumbo. Ele respondeu: "São os Portugueses que nos queriam recolonizar, e sujeitar a Portugal" e justificou sua resposta citando as tropas estrangeiras que eram mantidas no Brasil, as dez mil armas que o governo teria comprado, a preferência dos estrangeiros no comando das forças armadas e a formação de um Ministério composto por homens suspeitos. ${ }^{57}$ Este diálogo, portanto, revela que a crença na recolonização era justificada por fatos que supostamente comprovaria sua veracidade. O Europeu, mais cético, replicava que mesmo que houvesse um plano de recolonização, ele não fazia mais sentido com a saída do Imperador, sendo que o que importava naquele momento seria manter a união. Além disso, justificou a permanência dos portugueses no

\footnotetext{
${ }^{53} \mathrm{O}$ redator é desconhecido. Pode-se inferir que linha política do jornal é dos liberais moderados, pois suas posições críticas ao federalismo, entendido como uma ameaça a unidade do Brasil, são bem representativas desse grupo. Era impresso na Tipografia de Tomaz B. Hunt \& Cia. O exemplar custava 40 réis e saia às sextas-feiras. Circulou de 22 de abril de 1831 a 03 de julho de 1831. Encontram-se disponíveis os exemplares 1-3; 5-6. Segundo Nelson W. Sodré, o pasquim caracteriza-se por seu caráter efêmero e panfletário e por uma linguagem violenta e polêmica. SODRÉ, Nelson Werneck. História da imprensa no Brasil. Rio de janeiro: Civilização Brasileira, 1966, p.96-98. Entretanto, este pasquim não possui uma linguagem incendiária, o que pode ser explicado por ter sido lançado logo após a Abdicação, quando os liberais passaram a atuar para desradicalizar a movimentação que culminou com a Abdicação de D. Pedro I.

${ }^{54}$ CARVALHO, José M. de; BASTOS, Lúcia; BASILE, Marcello (orgs.). Introdução ao volume 3. In:__ Guerra literária: panfletos da Independência (1820-1823). Belo Horizonte: Editora UFMG, 2014, p.13.

${ }_{55}$ Como informou o pasquim, os brasileiros adotivos eram os portugueses residentes no Brasil quando ocorreu a Independência.

${ }^{56}$ Os Dois Compadres Liberais, $\mathrm{n}^{\circ} 1$ - 22/04/1831, p.3-4.

${ }^{57}$ Os Dois Compadres Liberais, nº2 - 29/04/1831, p.5.
} 
REVISTA ÁG으A, v. 31, n. 3, e-2020310307, 2020, ISSN: 1980-0096

Brasil em termos comerciais, ao argumentar que quando os portugueses conseguiam construir fortuna acabavam permanecendo no Brasil. ${ }^{58}$ Assim, para o Europeu, era hora de desradicalizar e apaziguar os ânimos, o que implicava frear o antilusitanismo, embora não negando integralmente que os portugueses representaram de fato uma ameaça aos interesses nacionais.

Esta preocupação com a desradicalização do movimento foi abraçada por outros jornalistas. Mesmo um publicista de discurso incendiário como Borges da Fonseca, redator do Republico, lançou um Manifesto, cinco dias após a Abdicação de D. Pedro I, para desmentir os boatos que ainda circulavam nas ruas do Rio de Janeiro. Fez elogios a "gloriosa revolução do 7 de abril" e pediu aos concidadãos que confiem no governo. Justificou que sua repentina moderação é determinada pela prudência, mas ressaltou que continuava vigilante, dizendo que "Se a Pátria necessitar que pelejeis por ela, eu serei o primeiro a avisar-vos, como o fui para vos armar contra o ingrato Pedro". Borges pediu aos soldados que respeitassem seus superiores e que não apoiassem os que contra eles se insubordinavam e nem aqueles que cometessem atos contra a segurança individual. Pediu aos soldados para não levarem as armas quando saírem para a cidade, que as deixassem no quartel. Avisou os concidadãos para não acreditarem em tudo o que se diz, citando o seguinte rifão: “em tempo de guerra mentira [é] como terra". ${ }^{9}$

A despeito de mudanças adotadas por D. Pedro I para reverter o declínio de sua popularidade após a Noite das Garrafadas, a oposição ao governo continuou e em 5 de abril de 1831, o Imperador demitiu todos os seus ministros e formou um novo Ministério composto de fidalgos que não desfrutavam de popularidade ${ }^{60}$. Em protesto, uma multidão de mais de três mil pessoas ${ }^{61}$ incluindo militares, líderes liberais e populares aglomerouse em um grande ajuntamento no Campo da Aclamação, para exigir a restituição do Ministério recém demitido ${ }^{62}$. D. Pedro I, entretanto, ignorou o protesto parecendo

\footnotetext{
${ }^{58}$ Os Dois Compadres Liberais, $\mathrm{n}^{\circ} 2$ - 29/04/1831, p.5-6.

${ }^{59}$ Manifesto Político de Antônio Borges da Fonseca, 12 de abril de 1831.

${ }^{60}$ ARMITAGE, João. História do Brasil. Brasília: Senado Federal, 2011, p.354-357.

${ }^{61}$ O major Miguel Frias estimou o ajuntamento em mais de três mil "cidadãos de consideração", ao relatar ao Imperador a situação complicada no Campo. Esta estimativa pode ter sido exagerada, talvez para conferir legitimidade à Abdicação. De qualquer modo, a presença no Campo dos vários regimentos militares indica a relevância política do acontecimento. FARIA, Silvério Cândido de. Breve história dos felizes acontecimentos políticos no Rio de Janeiro em os sempre memoráveis dias 6 e 7 de abril de 1831 remontada a epocha da viagem de Ex-Imperador à Província de Minas Gerais. Rio de Janeiro: Typ. De Thomaz B. Hunt e C., 1831, p.65-71. Esta estimativa é recorrentemente citada na historiografia. Ver: SOUSA, Octávio Tarquínio de. História dos Fundadores do Império do Brasil. A vida de D. Pedro I. Brasília: Senado Federal, 2015, v.3, p.831; SOUZA, 1999, p.348 e BASILE, Marcello. O laboratório da nação: a era regencial (1831-1840). In: GRINBERG, Keila; SALLES, Ricardo (Org.). O Brasil Imperial, volume II: 1831-1840. Rio de Janeiro: Civilização Brasileira, 2009, p.59.

${ }^{62}$ PANDOLFI, Fernanda..., 2007, p.133-141.
} 
REVISTA ÁG으A, v. 31, n. 3, e-2020310307, 2020, ISSN: 1980-0096

acreditar que ele logo se desfaria ${ }^{63}$. Não foi o que aconteceu; a adesão de tropas aumentou levando à abdicação em 7 de abril de 1831.

\section{CONCLUSÃO}

As novas demandas constitucionais dos atores políticos em 1831 certamente colocavam desafios ao governo de D. Pedro I e, em parte, explicam a perda da legitimidade de seu governo em 1831. Entretanto, neste artigo adotei um caminho diferente, que foi avaliar o papel das narrativas, neste processo, especificamente a da recolonização e a do Imperador antinacional, que se disseminaram em um curto intervalo de tempo, mobilizando setores da sociedade e criando um estado de tensão que levou o imperador a abdicar. As conclusões desta proposta foram sistematizadas em três explicações.

Em primeiro lugar, aponto o legado político recente da Revolução do Porto de 1820, enfatizando dois aspectos. O primeiro é o padrão seguido pela imprensa vintista que circulou no Brasil em 1821-1822, que divulgava principalmente escritos pautados por uma pedagogia cívica, mais próxima das formas orais de comunicação, que visavam atingir um público mais amplo. O segundo é o retorno em 1831 da narrativa vintista da recolonização, que se juntou a outras narrativas como a do Gabinete Secreto e a do Imperador antinacional.

Em segundo lugar ressalto o papel da imprensa em disseminar e amplificar sentimentos já enraizados nesta sociedade sob a forma de rumores, teorias conspiratórias e de relatos diversos. Tais narrativas exageravam tais sentimentos, misturando notícias falsas, suposições e fatos, com o objetivo de sensibilizar e unir os brasileiros para reagirem contra a ameaça do jugo português. Neste sentido, a culpa dos conflitos e demandas políticas e sociais já existentes na sociedade era atribuída a proteção dos portugueses pelo Imperador antinacional. Além disso, constantemente advertia que a recolonização do Brasil poderia piorar ainda mais esses conflitos e restabelecer, de fato, o jugo dos brasileiros pelos portugueses.

\footnotetext{
${ }^{63}$ FARIA, Silvério, 1831, p.65-71. Faria narra as várias tentativas de militares e ministros para convencer D. Pedro I da relevância do ajuntamento, o que sugere a hesitação de D. Pedro I em acreditar no que estava acontecendo.
} 
REVISTA ÁG으A, v. 31, n. 3, e-2020310307, 2020, ISSN: 1980-0096

A conclusão principal é que as narrativas, aqui entendidas como relatos que misturavam fatos, emoções e interesses humanos, afetaram a realidade política porque contêm elementos de autorrealização - isto é, produziram fatos objetivos que afetaram o mundo real. Mais exatamente, procurou-se mostrar como as narrativas disseminadas acabavam estimulando comportamentos que contribuíram para confirmar as próprias narrativas. Ainda que não se possa mensurar, em termos quantitativos, a intensidade com que as agressões entre portugueses e brasileiros aumentaram no período, as fontes sugerem que para os coevos esses conflitos eram generalizados. Tais sentimentos, assim, possivelmente estimularam mais conflitos que, progressivamente, foram sendo relatados pela imprensa. Essa mistura entre sentimentos e acontecimentos teve, ao que tudo indica, papel importante na deslegitimação do governo de D. Pedro I e, certamente, contribuiu para reunir a multidão da tropa e do povo no Campo de Santana um dia antes da Abdicação, cujas demandas e pressões o levaram a abdicar do trono. Após a Abdicação, redatores liberais, inclusive os chamados exaltados, vieram a público para tentar desradicalizar o movimento e frear o antilusitanismo que, percebiam, promoveria desordens capazes de abalar a própria ordem social.

Em termos mais amplos, o artigo pretende contribuir para matizar uma explicação ainda usual sobre este período da história, que caracteriza o Primeiro Reinado como uma época marcada pelo despotismo de um Imperador antinacional. Isto não significa, obviamente, que esta explicação, erigida pelos coevos, deva ser totalmente descartada, visto que teve importância nos embates políticos daquele momento, como nas narrativas que se sobrepuseram às tentativas de D. Pedro I para manter sua legitimidade. Mas que o suposto despotismo do Imperador deve ser analisado como peça de um jogo político que ocorria em um momento em que práticas políticas antigas e novas ainda coexistiam.

\section{REFERÊNCIAS}

\section{Fontes}

FARIA, Silvério Cândido de. Breve história dos felizes acontecimentos políticos no Rio de Janeiro em os sempre memoráveis dias 6 e 7 de abril de 1831 remontada a epocha da viagem de Ex-Imperador à Província de Minas Gerais. Rio de Janeiro: Typ. De Thomaz B. Hunt e C., 1831. 
REVISTA ÁG으A, v. 31, n. 3, e-2020310307, 2020, ISSN: 1980-0096

BIBLIOTECA NACIONAL. Aurora Fluminense, 1831.

. Novo Censor, 1831.

. O Republico, 1831.

. O Tribuno do Povo, 1831.

. Os Dois Compadres Liberais, 1831.

. MANIFESTO político de Antônio Borges da Fonseca, 12 de abril de 1831. Typograohia da Astréa, 1831.

TRANSLADO DO PROCESSO a que deu motivo os tumultos das Garrafadas do dia 13, 14 e 15 de março de 1831. Cópia. Manuscrito. 35 p. Consta na capa: "As Garrafadas".

\section{Obras Gerais}

ANDRADE, Marcos Ferreira de \& SILVA, Janaína de Carvalho. Moderados, exaltados e caramurus no prelo carioca: os embates e as representações de Evaristo Ferreira da Veiga (1831-1835). Almanack, Guarulhos, n. 4, p. 130-148, 2012.

ARMITAGE, João. História do Brasil. Brasília: Senado Federal, 2011.

BASILE, Marcello. O laboratório da nação: a era regencial (1831-1840). In: GRINBERG, Keila; SALLES, Ricardo (Og.). O Brasil Imperial, volume II: 1831-1840. Rio de Janeiro: Civilização Brasileira, 2009. 2001.

Ezequiel Corrêa dos Santos: um jacobino na corte imperial. Rio de Janeiro: FGV,

BERBEL, Márcia Regina. A retórica da recolonização. In: JANCSÓ, I. (Org.). Independência: história e historiografia. São Paulo: Hucitec, 2005.

CAMPOS, Adriana Pereira. Magistratura eleita: administração política e judicial no Brasil (1826-1841). Almanack, Guarulhos, n. 18, p. 97-138, 2018.

CARVALHO, José M. de; BASTOS, Lúcia; BASILE, Marcello (Org.). Introdução ao volume 3. In:__ Guerra literária: panfletos da Independência (1820-1823). Belo Horizonte: Editora UFMG, 2014, p.11-22.

COSER, Ivo. O conceito de federalismo e a ideia de interesse no Brasil no século XIX. Dados. Rio de Janeiro, v.51, n.4, p.946-981, 2008.

CUPELLO, Rafael. "Tradicionalistas" x "Conservadores": uma disputa palaciana na Corte de D. Pedro I. In: CAMPOS, Adriana Pereira; RIBEIRO, Geisa Lourenço; SIQUEIRA, Karulliny Silverol; MOTTA, Katia Sausen da (Org). Entre as províncias e a 
REVISTA ÁG요A, v. 31, n. 3, e-2020310307, 2020, ISSN: 1980-0096

nação: os diversos significados da política no Brasil do Oitocentos. Vitória: Editora Milfontes, 2019.

ELLEY, Geoff. Nations, publics and political cultures: placing Habermas in nineteenth century. In: CALHOUN, Craig (ed.). Habermas and the public sphere. London: MIT Press, 1992, p.289-339.

FARGE, Arlette. Subversive Words: public opinion in Eighteenth-century France. Pennsylvania State University Press, 1994.

HABERMAS, Jürgen. Mudança estrutural na esfera pública. Rio de Janeiro: Tempo Brasileiro, 1984.

JANCSÓ, István; PIMENTA, João P.G. Peça de um mosaico (apontamentos para o estudo da emergência da identidade nacional brasileira). In: MOTA, Carlos Guilherme (Org.). Viagem Incompleta: a experiência brasileira (1500-2000) São Paulo: SENAC, v. 1, p.129-175, 2000.

KARASCH, Mary C. A vida dos escravos no Rio de Janeiro (1808-1850). São Paulo: Companhia das Letras, 2000

LEFEBVRE, Georges. O Grande Medo de 1789. Rio de Janeiro: Campus, 1979.

LENHARO, Alcir. As tropas da moderação: o abastecimento da Corte na formação política do Brasil (1808-1842). São Paulo: Símbolo, 1979.

LUSTOSA, Isabel. Insultos impressos: a guerra dos jornalistas na Independência (18211823). São Paulo: Companhia das Letras, 2000.

Insultos impressos: o nascimento da imprensa no Brasil. In: MALERBA, Jurandir (Org.). A Independência brasileira: novas dimensões. Rio de Janeiro: FGV, 2006.

MANIN, Bernard. Los princípios del gobierno representativo. Madrid: Alianza Editorial, 1998.

MARQUES JÚNIOR, Nelson Ferreira. O despertar do Império independente: áulicos e a formação de um projeto de Brasil na Corte fluminense (1822-1831). Tese (Doutorado em História), Universidade Federal Rural do Rio de Janeiro, Seropédica (RJ), 2018.

MOREL, Marco. As transformações dos espaços públicos: imprensa, atores políticos e sociabilidade na cidade imperial (1820-1840). São Paulo: Hucitec, 2005.

. Os primórdios da imprensa no Brasil. In: MARTINS, A.; LUCA, T. (Org.). História da imprensa no Brasil. São Paulo: contexto, 2012. E-book, Kindle Edition.

NEVES, Lúcia Maria Bastos; MACHADO, Humberto Fernandes. Portugueses e brasileiros? In: . O Império do Brasil. Rio de Janeiro: Nova Fronteira, 1999.

Cidadania e participação política na época da Independência do Brasil. Cadernos Cedes, Campinas, v. 22, n. 58, p. 47-64, dez. 2002. 
Opinión Pública. In: FERNÁNDEZ SEBASTIÁN, Javier (dir.). Diccionario político y social del mundo iberoamericano: la era de las revoluciones, 1750-1850. Madrid: Fundación Carolina, 2009.

NUNES, Tassia Toffoli. Liberdade de imprensa no Império brasileiro: os debates parlamentares (1820-1840). Dissertação (Mestrado em História), Universidade de São Paulo, São Paulo, 2010.

PANDOLFI, Fernanda Cláudia. A abdicação de D. Pedro I: espaço público da política e opinião pública no final do Primeiro Reinado. Tese (Doutorado em História), Universidade Estadual Paulista, Assis, 2007.

Política, imprensa e a participação dos militares na Abdicação de Dom Pedro I. História Unisinos, São Leopoldo (RS), v.16, n.3, 2012, p.283-293.

. O papel da imprensa na política no final do Primeiro Reinado: uma análise do jornal Tribuno do Povo. História e Cultura, Franca, v.3, n.3, 2014, p.325-343.

Rumores e política no Rio de Janeiro e em Minas Gerais no final do Primeiro Reinado. História (São Paulo), Franca, v. 33, n. 2, p. 307-322. 2014.

REIS, Arthur Ferreira. "Anarquistas" e "servis": uma análise dos projetos políticos do ano de 1826 no Rio de Janeiro. Dissertação (Mestrado em História), Universidade Federal do Espírito Santo, Vitória, 2016.

RIBEIRO, Gladys S. A liberdade em construção: identidade nacional e conflitos antilusitanos no primeiro reinado. Rio de Janeiro: RelumeDumará/FAPERJ, 2002.

ROCHA, Antonio Penalves. A recolonização do Brasil pelas Cortes: história de uma invenção historiográfica. São Paulo: Editora UNESP, 2008.

ROWLAND, Robert. Patriotismo, povo e ódio aos portugueses: notas sobre a construção da identidade nacional no Brasil independente. In: JANCSÓ, Instván (org.). Brasil: formação do Estado e da nação. São Paulo: Hucitec, 2003.

SHILLER, Robert J. Narrative economics: how stories go viral \& drive major economics events. New Jersey: Princeton University Press, 2019.

SODRÉ, Nelson Werneck. História da imprensa no Brasil. Rio de janeiro: Civilização Brasileira, 1966.

SOUSA, Octavio Tarquínio de. História dos fundadores do Império do Brasil: a vida de d. Pedro I. Rio de Janeiro: José Olympio, 1957. v. 4.

História dos Fundadores do Império do Brasil. A vida de D. Pedro I. Brasília: Senado Federal, 2015, v.3.

SOUZA, Iara Lis Carvalho. Pátria coroada: o Brasil como corpo político autônomo (1780-1831). São Paulo: UNESP, 1999. 
REVISTA ÁG으A, v. 31, n. 3, e-2020310307, 2020, ISSN: 1980-0096

TACKETT, Timothy. Rumor and Revolution: the case of the September Massacres. French History \& Civilization, v. 4, 2011.

VIANNA, Helio. Contribuição à história da imprensa brasileira (1812-1869). Rio de Janeiro: Imprensa Nacional, 1945.

D. Pedro I e D. Pedro II. Rio de Janeiro: Nacional, 1966.

Recebido em: 21/10/2020 - Aprovado em: 31/03/2021 